\title{
PEMBELAJARAN BIOLOGI DENGAN MODEL POE (PREDICT- OBSERVE-EXPLAIN) MENGGUNAKAN MULTIMEDIA FLASH DAN VCD DITINJAU DARI KEMAMPUAN VERBAL DAN KREATIVITAS SISWA
}

\author{
Nawawi $^{1}$, Sugiyarto ${ }^{2}$ dan Sutarno ${ }^{3}$ \\ ${ }^{1}$ SMK PALEBON SEMARANG \\ Semarang, 50139, Indonesia \\ media_edukasi73@yahoo.co.id \\ ${ }^{2}$ Pendidikan Sains, Pascasarjana, Universitas Sebelas Maret \\ sugiyarto_ys@yahoo.com \\ ${ }^{3}$ Pendidikan Sains, Pascasarjana, Universitas Sebelas Maret \\ nnsutarno@yahoo.com
}

\begin{abstract}
This study is intended to find the influence of the Multimedia Flash and VCD in the teaching and learning of plant movement that used POE learning model overviewed from verbal ability and student's creativity. The research took $2^{\text {nd }}$ graders of SMP Nuris Semarang. The research took place in the beginning of the second semester of 2011/2012 academic year. There were two classes selected at Nuris junior high school as research groups. The research instruments were in the forms of lesson plan, teaching-learning materials, students activity sheets, observation sheets, tests. The influence of Multimedia Flash and VCD on the students 'learning results and data's were analysed by ANOVA with three way analysis of variances. The study showed that (1) there were no effect of the use of Multimedia Flash and VCD with POE learning model, (2) there were an effect of verbal ability on affective and psychomotor aspect, (3) there was no effect of creativity for achievement affective and psychomotor aspect, but there is an influence of cognitive aspect, (4) there was no interaction between Multimedia Flash and VCD with verbal ability on achievement affective and psychomotor aspect, but there is an interaction influence for cognitive aspect, (5) there was an interaction on creativity with Multimedia Flash and VCD from cognitive and affective aspect, (6) there were no interaction between verbal ability and creativity of students, (7) there were no interaction between Multimedia Flash and VCD, verbal ability and creativity for cognitive, affective and psychomotor.
\end{abstract}

Keywords: Media Education, Verbal Ability, Creativity and Plants Movement

\section{Pendahuluan}

Proses pembelajaran IPA (Biologi) tidak cukup dilaksanakan dengan menyampaikan informasi tentang konsep-konsep dan prinsipprinsip, tetapi peserta didik juga harus memahami proses terjadinya fenomena sains dengan memanfaatkan penginderaan sebanyak mungkin. Ini berarti pada saat belajar sains, peserta didik harus aktif dalam proses pembelajaran melalui kegiatan pengamatan, eksperimen dan berdiskusi dengan teman atau dengan guru, kegiatan tersebut secara populer dikenal dengan "hands-on and minds-on activity" yang dapat diartikan bahwa belajar dapat dilakukan melalui aktivitas pengetahuan (knowledge) dan praktek (praktikum). Pendidikan bukan hanya merupakan suatu proses transfer of knowledge yang dilakukan oleh guru kepada anak didiknya. Melainkan, pendidikan adalah alat untuk merubah cara berpikir dari cara berpikir tradisional ke cara berpikir ilmiah (modern).

Pendidikan di Indonesia pada umumnya masih berlangsung dengan pengajaran yang dilakukan dengan cara mentransfer pengetahuan dari guru kepada peserta didik dan peserta didik harus menyimpan dalam ingatannya. Menurut (Nurjanah, 2010:1) Jean Piaget seorang pioner filsafat konstruktivisme menyatakan bahwa dalam proses belajar anak- 
anak akan membangun sendiri skemanya serta membangun konsep-konsep melalui pengalaman-pengalaman. Hal tersebut menunjukkan bahwa guru tidak begitu saja memberikan pengetahuan kepada peserta didik, melainkan peserta didiklah yang harus aktif membangun pengetahuannya sendiri.

Berdasarkan pengamatan yang dilakukan di kelas VIII SMP Nuris Semarang bahwa nilai prestasi peserta didik masih jauh dari yang diharapkan. Rendahnya mutu hasil belajar sains (Biologi) tersebut dapat dilihat dari nilai pada Tabel 1 .

Tabel 1. Nilai rata-rata IPA kelas VIII

\begin{tabular}{|c|c|c|}
\hline Kelas & KKM & $\begin{array}{l}\text { Nilai rata-rata } \\
\text { IPA }\end{array}$ \\
\hline "VIII A & $\begin{array}{l}7,00 \\
\end{array}$ & 6,20 \\
\hline VIII B & 7,00 & 6,92 \\
\hline
\end{tabular}

Sumber : hasil ulangan tengah semester kelas VIII, 2012

Hasil analisa menunjukkan bahwa prestasi belajar sains masih rendah, hal ini dapat terjadi karena siswa kurang aktif dalam menggali informasi materi IPA, dominasi guru masih lebih besar dibandingkan keaktifan siswa dalam pembelajaran, metode ceramah dan tugas yang diberikan belum sepenuhnya mengatasi kesulitan siswa. Kemampuan pemahaman siswa dalam menerima materi IPA perlu ditingkatkan dan keaktifan siswa dalam menyalurkan pendapat perlu dilatih sesuai dengan kemampuan kognitifnya.

Pembelajaran Biologi di tingkat SMP merupakan bagian dari Ilmu Pengetahuan Alam, salah satu materi yang dipelajari di kelas VIII adalah tentang gerak pada tumbuhan yang meliputi faktor yang mempengaruhi gerak dan proses gerak pada tumbuhan.

Materi gerak pada tumbuhan sangat sulit diajarkan karena proses gerak pada tumbuhan yang tidak dapat diamati langsung,dimana proses gerak pada tumbuhan dapat terjadi pada siang hari, sore hari ataupun pada malam hari. Karakteristik materi pada gerak pada tumbuhan adalah materi bersifat riil atau kongkrit namun sulit diamati karena membutuhkan waktu yang lama dalam pengamatan, serta banyak menggunakan ejaan/kata-kata ilmiah yang dirasakan sulit bagi siswa.

Untuk mempermudah atau memperjelas proses gerak pada tumbuhan tersebut dapat dibuat animasi dan video proses gerak pada tumbuhan. Maka untuk mengatasi hal tersebut, dibutuhkan suatu alat bantu/media yang dapat mengambarkan benda nyata, mengatasi kendala keterbatasan waktu pengamatan oleh peserta didik dalam mengamati gerak pada tumbuhan secara langsung dalam waktu terbatas. Maka guru dapat menggunakan media animasi atau video gerak tanaman.

Fenomena rendahnya partisipasi peserta didik perlu mendapat perhatian, dicari penyebabnya, dan segera mencari solusinya. Upaya meningkatkan partisipasi peserta didik dalam pembelajaran merupakan hal yang penting untuk dilakukan, karena terkait erat dengan keberhasilan pendidikan, sehingga diperlukan dukungan dan upaya untuk mengatasi hal tersebut.

Kurangnya partisipasi aktif peserta didik dalam setiap kegiatan pembelajaran dalam memahami konsep-konsep, mengakibatkan pemahaman konsep materi masih kurang optimal sehingga hasil belajar yang dicapai peserta didik masih rendah. Agar hal itu tidak terjadi, perlu dilakukan berbagai upaya salah satunya adalah menentukan model/metode pembelajaran yang dapat melibatkan peserta didik secara aktif dalam kegiatan pembelajaran.

Model Pembelajaran POE (PredictObserve-Explain) adalah model pembelajaran dengan urutan proses membangun pengetahuan dengan terlebih dahulu meramalkan solusi dari permasalahan, lalu melakukan eksperimen atau observasi untuk membuktikan ramalan dan terakhir menjelaskan hasil eksperimen atau observasi White dan Gustone (dalam Kearney, 2001).

Keunggulan Model POE dalam pembelajaran IPA (Biologi) adalah, model POE memiliki langkah-langkah pembelajaran (sintaks) yaitu Prediction, Observation dan Explanation. Langkah-langkah dalam model POE ini sangat cocok apabila diterapkan dalam pembelajaran materi gerak pada tumbuhan. Karena karakteristik dari materi gerak pada tumbuhan adalah bendanya nyata namun terdapat keterbatasan waktu pengamatan, dengan menggunakan model POE maka peserta didik diminta untuk memprediksi macam-macam gerak yang terjadi pada tumbuhan melalui gambar atau tayangan animasi dan video. Selanjutnya 
peserta didik diminta melakukan pengamatan melalui media kemudian peserta didik diminta untuk menjelasakannya.

Berdasarkan fakta dan permasalahan diatas, dilakukan penelitian untuk membandingkan Multimedia Flash dan media VCD tentang gerak pada tumbuhan. Selanjutnya akan dilihat pengaruhnya terhadap prestasi belajar peserta didik yang ditinjau dari kreativitas peserta didik dan kemampuan verbal.

Penelitian ini bertujuan untuk (1) mengetahui pengaruh penggunaan Multimedia Flash dan Media VCD terhadap prestasi belajar IPA pada materi gerak pada tumbuhan; (2) mengetahui pengaruh kemampuan verbal terhadap prestasi belajar IPA pada materi gerak pada tumbuhan; (3) mengetahui pengaruh kreativitas terhadap prestasi belajar IPA pada materi gerak pada tumbuhan; (4) mengetahui interaksi antara media pembelajaran dan kreativitas siswa terhadap prestasi belajar peserta didik; (5) mengetahui interaksi antara media pembelajaran dan kemampuan verbal terhadap prestasi belajar; (6) mengetahui interaksi antara kreativitas dan kemampuan verbal terhadap prestasi belajar; (7) mengetahui interaksi antara media pembelajaran, kreativitas peserta didik dan kemampuan verbal terhadap prestasi belajar.

\section{Metode Penelitian}

Pelaksanaan penelitian mencakup tahaptahap persiapan (perijinan dan diskusi dengan guru di sekolah uji coba dan sasaran), pembuatan instrumen (Silabus dan RPP), uji coba soal, pelaksanaan pengambilan data, analisis data, dan penyusunan laporan penelitian. Subyek penelitian adalah siswa kelas VIII SMP Nuris Semarang sebanyak dua kelas sebagai kelas eksperimen dengan menggunakan media yang berbeda. Pemilihan dua kelas sebagai sampel penelitian di tiap sekolah berdasarkan kesetaraan kemampuan siswa di kedua kelas tersebut.

Instrumen penelitian ini mencakup: silabus, rencana pelaksanaan pembelajaran, media pembelajaran (Multimedia Flash dan VCD), soal tes kemampuan verbal, soal tes kreativitas, soal tes evaluasi yang meliputi ranah kognitif,afektif dan psikomotorik. Tes kemampuan verbal dan tes kreativitas diujikan terlebih dahulu kemudian setelah pelaksanaan pembelajaran selesai dan dua minggu kemudian dilaksanakan tes kognitif, afektif dan psikomotorik). Instrumen-instrumen tersebut di atas diverifikasi terlebih dahulu sebelum digunakan untuk mengambil data penelitian. Pelaksanaan pembelajaran dalam bulan April-Mei 2012.

Data penelitian berupa: data kemampuan verbal, kreativitas, data hasil belajar siswa setelah 2 minggu pembelajaran berlalu. Data dalam penelitian ini akan dianalisis untuk dapat membandingkan subyek yang menjadi sampel dan kontrol. Penelitian ini menggunakan rancangan dengan desain faktorial $2 \times 2 \times 2$.

Data kemampuan verbal diperoleh setelah dilaksanakan tes kemampuan verbal. Data tentang kemampuan verbal peserta didik dikategorikan dalam dua tingkatan berdasarkan nilai rata-rata peserta didik, yaitu kategori tinggi dan kategori rendah. Kemampuan verbal peserta didik dikategorikan tinggi apabila nilai tes yang diperoleh lebih besar atau sama dengan nilai rata-rata tes kemampuan verbal. Sedangkan kemampuan verbal dikategorikan rendah apabila tes yang diperoleh kurang dari nilai tes rata-rata kemampuan verbal.

\section{Hasil Penelitian dan Pembahasan}

Berdasarkan hasil penelitian yang telah dilakukan, maka diperoleh data prestasi belajar siswa yang meliputi ranah kognitif, psikomotorik dan afektif.

Data prestasi belajar menggunakan Multimedia Flash dan VCD dengan model POE pada penelitian ini meliputi tiga aspek yaitu aspek kognitif, aspek psikomotorik dan aspek afektif. Adapun data prestasi belajar siswa disajikan pada Tabel 2 .

Tabel 2. Prestasi Belajar Ranah Kognitif, Psikomotorik dan Afektif Berdasarkan Media Pembelajaran

\begin{tabular}{llll}
\hline \hline & \multicolumn{3}{c}{ Nilai rata-rata } \\
\cline { 2 - 4 } \begin{tabular}{l} 
Media \\
\cline { 2 - 4 } Pembelajaran
\end{tabular} & Kognitif & Psikomotorik & Afektif \\
\hline \hline Multimedia Flash & $70,05 \mathrm{a}$ & $71,00 \mathrm{a}$ & $76,65 \mathrm{a}$ \\
VCD & $72,25 \mathrm{a}$ & $73,25 \mathrm{a}$ & $72,25 \mathrm{a}$ \\
\hline
\end{tabular}


Keterangan: angka yang diikuti huruf yang sama tidak berbeda nyata pada uji anava dengan taraf signifikansi $95 \%$.

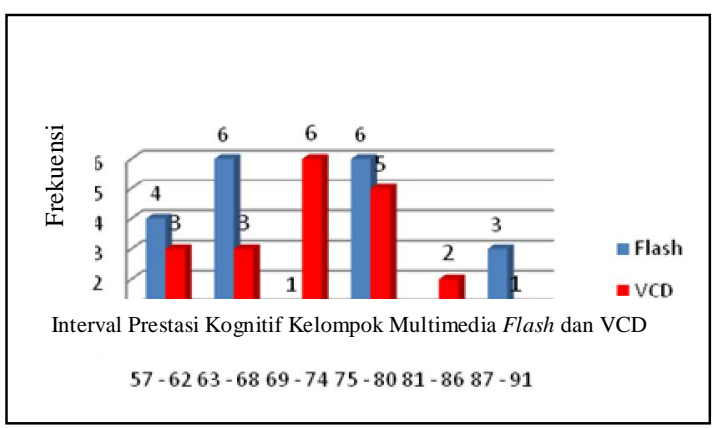

Gambar 1. Histogram Prestasi Kognitif Kelompok Multimedia Flash dan VCD Pembelajaran

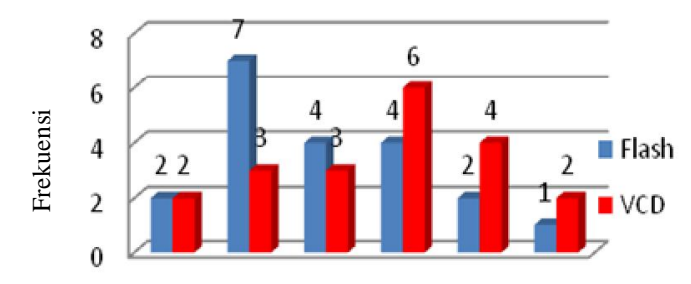

$50-5758-65 \quad 66-7374-8182-8990-98$

Interval Prestasi Psikomotorik Kelompok Multimedia Flash dan VCD

Gambar 2. Histogram Prestasi Psikomotorik Kelompok Multimedia Flash dan VCD Pembelajaran

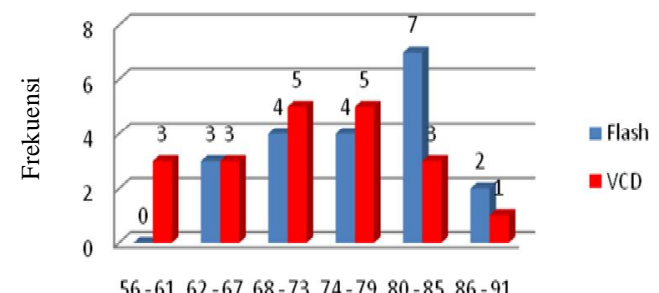

Interval Prestasi Afektif Kelompok Multimedia Flash dan VCD

Gambar 3. Histogram Prestasi Afektif Kelompok Multimedia Flash dan VCD Pembelajaran

Data tentang kemampuan verbal peserta didik dikategorikan dalam dua tingkatan berdasarkan nilai rata-rata peserta didik, yaitu kategori tinggi dan kategori rendah. Data prestasi belajar ranah kognitif, psikomotorik dan afektif berdasarkan kemampuan verbal ditunjukkan pada Tabel 3.
Tabel 3. Prestasi Belajar Berdasarkan Kemampuan Verbal

\begin{tabular}{lcccc}
\hline & & \multicolumn{3}{c}{ Mean } \\
Media & Vemampuan & \multicolumn{3}{c}{} \\
\hline \multirow{2}{*}{ Flash } & Tinggi & Kognitif & Psikomotorik & Afektif \\
& Rendah & 64 & 71 & 79 \\
\multirow{2}{*}{ VCD } & Tinggi & 75 & 77 & 75 \\
& Rendah & 68 & 68 & 69 \\
& & & &
\end{tabular}

Data tentang kreativitas peserta didik dikategorikan dalam dua tingkatan berdasarkan nilai rata-rata peserta didik, yaitu kategori tingi dan kategori rendah. Data prestasi belajar ranah kognitif, psikomotorik dan afektif berdasarkan kreativitas siswa ditunjukkan pada Tabel 4.

Tabel 4. Prestasi Belajar Berdasarkan Kreativitas Siswa

\begin{tabular}{lllll}
\hline \multicolumn{5}{c}{ Mean } \\
& Kreativitas & Kognitif & Psikomotorik & Afektif \\
\hline \hline \multirow{2}{*}{ Flash } & Tinggi & 75 & 68 & 78 \\
& Rendah & 66 & 73 & 75 \\
\multirow{2}{*}{ VCD } & Tinggi & 78 & 74 & 73 \\
& Rendah & 63 & 72 & 70 \\
\hline
\end{tabular}

Data-data yang di peroleh dari hasil penelitian yang berupa skor kemampuan verbal, kreativitas siswa, nilai prestasi belajar kognitif, afektif dan psikomotor dianalisis dengan analisis variansi tiga jalan $(2 \times 2 \times 2)$ dengan taraf signifikansi 0,05 dan menggunakan bantuan software PASW 18.

Tabel 5. Rangkuman Hasil Uji Anova pada ranah afektif, psikomotorik dan afektif

\begin{tabular}{llll}
\hline \hline \multicolumn{1}{c}{ Yang di Uji } & Kognitif & Psikomotorik & Afektif \\
\cline { 2 - 4 } & P-Value & P-Value & P-Value \\
\hline \hline Media Pembelajaran & 0,603 & 0,593 & 0,176 \\
Kemampuan verbal & $0,000 \mathrm{~s}$ & 0,552 & 0,106 \\
Kreativitas & $0,000 \mathrm{~s}$ & 0,148 & 0,247 \\
Media*Kemampuan & & & \\
Verbal & $0,033 \mathrm{~s}$ & 0,439 & 0,626 \\
Media*Kreativitas & $0,017 \mathrm{~s}$ & 0,371 & 0,041 \\
Kemampuan & & & 0,375 \\
Verbal*Kreativitas & 0,653 & 0,391 & \\
Media*Kemampuan & & & 0,133 \\
Verbal*Kreativitas & 0,358 & 0,752 & \\
\hline
\end{tabular}

Keterangan : $*=$ Interaksi, angka yang diikuti huruf yang sama tidak berbeda nyata pada uji anava dengan taraf signifikansi $95 \%$. 
Hasil penelitian yang dilakukan menunjukkan bahwa siswa yang belajar dengan menggunakan media VCD mencapai hasil belajar yang lebih tinggi dari pada siswa yang belajar menggunakan Multimedia Flash.

Data pada Tabel 3, dapat diperoleh informasi bahwa siswa dengan kemampuan verbal tinggi paling terbantu oleh media VCD Pembelajaran, sehingga prestasi belajarnya tinggi. Sebaliknya siswa dengan kemampuan verbal rendah paling tidak terbantu dengan penggunaan Multimedia Flash dalam pembelajaran sehingga prestasinya rendah.

Hasil penelitian serupa yang dilakukan oleh Wikara (2010) menjelaskan bahwa dengan adanya teks/tulisan dalam media pembelajaran berbasis animasi dan komik dapat mempengaruhi prestasi belajar siswa, sejalan dengan hal tersebut Mayer\&Sims (dalam Koroghlanian; 2004) menyatakan bahwa beberapa penelitian tentang animasi dengan narasi audio lebih efektif daripada animasi tanpa audio.

Media pembelajaran yang berupa VCD Pembelajaran mengandung lebih banyak narasi/audio dan sedikit tulisan, hal ini berlainan dengan Multimedia Flash yang lebih banyak teks, animasi daripada narasi/audio. Multimedia Flash lebih banyak dilengkapi dengan animasi dan teks serta video dengan musik pengiring, sehingga dirasa kurang membantu bagi siswa yang memiliki kemampuan verbal rendah. Faktor lain yang dirasa mempengaruhi adalah faktor eksternal, yaitu motivasi siswa dalam belajar biologi menggunakan Multimedia Flash dirasakan oleh guru sangat kurang. Hal ini dapat terjadi karena dalam Multimedia Flash lebih banyak animasi yang menyebabkan siswa masih kurang memahami visual/gambar animasi yang ditampilkan, lain halnya dengan VCD Pembelajaran dimana visualisasi diambil langsung dari alam atau mengambil contoh tanaman yang ada di lingkungan sekitar siswa, sehingga siswa lebih cepat dan mudah dalam memproses visual/gambar menjadi kata$\mathrm{kata} / \mathrm{verbal}$.

Adapun kelemahan dalam pembelajaran menggunakan Multimedia Flash dan VCD ini adalah: (1) sound atau suara yang dihasilkan dari Multimedia Flash masih terlalu kecil, sehingga membutuhkan alat bantu speaker; (2) animasi di dalam Multimedia Flash masih sangat sedikit sehingga perlu ditambah lagi;. (3) keterlibatan siswa dalam pembelajaran menggunakan Multimedia Flash masih belum maksimal, hal ini ditunjukkan oleh masih banyaknya siswa yang tidak memperhatikan media pembelajaran ketika ditayangkan; (4) kurangnya waktu persiapan guru dalam menyusun lembar kerja siswa yang telah di integrasikan dengan Multimedia Flash, lembar kerja siswa hendaknya menggunakan soal-soal problem solving sehingga mampu mengoptimalkan kemampuan siswa dalam mencari dan menyelesaikan soal-soal tersebut; (5) terbatasnya waktu pembuatan media, karena media yang baik itu hendaknya dibuat oleh tim yang terdiri dari pakar multimedia dan pemrograman flash, pakar materi Biologi atau dosen Biologi, dan ahli bahasa. Sementara dalam penelitian ini peneliti membuatnya sendiri; (6) guru hendaknya memimpin jalannya pembelajaran karena semangat siswa untuk menyelesaikan soal-soal dalam lembar kerja siswa membuat siswa berdiskusi sehingga akhirnya suasana menjadi ramai. Guru yang baik hendaknya mampu mengontrol dan menjadi fasilitator bagi siswa dalam berdiskusi.

Adapun kelebihan dalam pembelajaran menggunakan Multimedia Flash dan VCD menggunakan model POE adalah: (1) animasi yang ditayangkan membantu mempermudah siswa dalam memahami materi pelajaran; (2) video yang ditampilkan membuat siswa lebih termotivasi untuk belajar; (3) adanya diskusi tanya jawab melalui lembar kerja siswa dalam pembelajaran menggunakan media menjadikan siswa aktif dalam berifikir dan meningkatan aktivitas di dalam kelas, hal ini sejalan dengan dengan (Sumarni, 2009) yang menyatakan bahwa tanya jawab menjadikan siswa lebih aktif dalam berifikir kritis; (4) siswa menjadi lebih mampu membuat prediksi berdasarkan sejumlah keterangan atau gambar yang disajikan melalui tayangan gambar atau video; (5) penggunaan media mampu mendorong siswa untuk berfikir tingkat tinggi, karena media mampu menyajikan permasalahan pada materi gerak pada tumbuhan yang sulit atau terbatas dalam proses pengamatannya. Hal ini sejalan dengan (Sumarni, 2009) yang menyatakan media audio-visual dapat membantu siswa dalam memahami konsep abstrak dan kompleks; (6) penggunaan Model 
POE dan Media pembelajaran menjadikan pembelajaran lebih menarik karena dapat memperkuat ingatan siswa pada materi gerak pada tumbuhan, serta mampu mendorong siswa untuk mengoptimalkan penggunaan panca indera karena semakin banyak alat indera yang dipergunakan dalam proses pembelajaran maka akan berpengaruh besar terhadap hasil belajar siswa.

Data Tabel 4 menyatakan bahwa penggunaan Multimedia Flash dan VCD pada siswa dengan kreativitas rendah tidak memberikan efek yang signifikan bila dibandingkan siswa dengan kreativitas tinggi pada ranah kognitif, namun siswa dengan kreativitas rendah memperoleh nilai yang lebih tinggi dibandingkan siswa dengan kreativitas rendah pada ranah psikomotorik dan afektif.

Kreativitas merupakan hal yang berbeda dengan kemampuan verbal. Kreativitas menekankan pada pemikiran atau perbuatan yang bersifat imajinatif atau menyimpang dari kebiasaa. Menurut Brian Clegg dan Paul Birch (dalam Wikara; 2010) kreativitas yang dimiliki oleh siswa akan mati atau berkurang jika terdapat pembelajaran yang otoriter. Pembelajaran otoriter yang dimaksud adalah pembelajaran yang hanya mementingkan penyampaian materi saja atau teacher centered learning, dimana peserta didik tidak mendapatkan kesempatan untuk aktif dan mengembangkan keterampilannya dalam berproses untuk memperoleh pengetahuan. Siswa yang kreatif juga adalah seorang yang menyukai tantangan, seseorang yang mampu menyampaikan ide-ide atau gagasannya baik lisan maupun tertulis, serta memiliki imajinasi yang tinggi.

Menurut Munandar (1990) "Kreativitas adalah kemampuan yang mencerminkan kelancaran, keluwesan atau fleksibilitas, orisinalias dalam berfikir serta kemampuan untuk mengelaborasi (mengembangkan, memperkaya, memperinci gagasan). Oleh karena itu siswa yang memiliki ciri tersebut tergolong siswa kreatif. Hal ini sejalan dengan Feasey (dalam Liversidge et al, 2009:162) Orang kreatif adalah orang yang berfikir bebas, pemberani, berpikir tentang banyak sekali ide-ide dan tidak hanya satu ide saja, selalu berfikir hal-hal baru, memiliki cita-cita yang tinggi, dapat mendorong dan menyenangkan orang lain serta memliki imajinasi yang tinggi.

Fautley \& Savage (dalam Liversidge et al, 2009:166) mengidentifikasi empat kunci pembelajaran yang kreatif, yaitu kenikmatan, motivasi, pengalaman belajar dan berpikir divergen. Siswa yang kreatif adalah orang yang berani menyampaikan ide-idenya, orang yang memiliki imajinasi tinggi, dan berpandangan jauh ke depan. Sehingga siswa yang memiliki kreativitas rendah mampu memperoleh nilai yang lebih baik pada ranah psikomotorik dan afektif dapat disebabkan oleh faktor internal dan kemauan siswa dalam berkreasi, berimajinasi dan menyelesaikan masalah.

Menurut Winkel dalam Wikara (2010:28) "Kemampuan verbal merupakan pengetahuan yang dimiliki seseorang yang dapat diungkapkan dalam bentuk bahasa, lisan dan tertulis". Sedangkan menurut Ackerman \& Lohman (dalam Matthew\&Alice, 2010:289) menyatakan bahwa pembaca dengan kemampuan verbal yang lebih tinggi akan mengingat informasi lebih lama dibandingkan dengan kemampuan verbal yang lebih rendah karena kemampuan verbal adalah kunci yang kuat dalam pemahaman membaca. Sedangkan penelitian sebelumnya telah menunjukkan bahwa kemampuan verbal tinggi akan mampu mengingat teks lebih baik dari pembaca yang memiliki kemampuan verbal yang lebih rendah (dalam Matthew\&Alice, 2010:289). Hasil penelitian ini sejalan penelitian yang dilakukan peneliti bahwa siswa yang memiliki kemampuan verbal tinggi mendapatkan hasil yang lebih baik dibandingkan dengan siswa yang miliki kemampuan verbal rendah.

Hasil penelitian menunjukkan bahwa siswa yang memiliki kemampuan verbal tinggi merasakan kemudahan karena media yang dipergunakan dilengkapi dengan teks dan narasi daripada siswa dengan kemampuan verbal rendah. Sedangkan untuk kreativitas tinggi, seperti diuraikan pada analisa hipotesis ketiga, lebih menyukai hal-hal yang bersifat imajinatif, gambar atau video yang dilengkapi pertanyaan dapat merangsang siswa untuk menyampaikan pendapat atau ide-idenya melalui kegiatan diskusi. Sebaliknya siswa degan kreativitas rendah tidak cocok dengan media tersebut yang berakibat prestasi belajarnya lebih rendah dibandingkan siswa 
yang mempunyai kreativitas tinggi, maka inilah yang menyebabkan tidak terjadinya interaksi.

Tidak adanya interaksi yang signifikan dari uji lanjut pasaca anava antara media pembelajaran, kemampuan verbal dan kreativitas dapat dijelaskan sebagai berikut; Multimedia Flash dan VCD Pembelajaran seperti telah dibahas sebelumnya mengandung dua unsur yang sama yaitu gambar/visual yang dipadukan dengan teks/tulisan. Kedua hal ini dikombinasikan sedemikian rupa sehingga menghasilkan media pembelajaran yang menarik bagai siswa. Hanya saja untuk VCD Pembelajaran dilengkapi dengan narasi sedangkan untuk Multimedia Flash tidak dilengkapi dengan narasi. Multimedia Flash lebih banyak dilengkapi dengan animasi bila dibandingkan dengan VCD Pembelajaran.

Kedua media pembelajaran sama-sama kurang dilengkapi pertanyaan yang bersifat problem solving, dimana pertanyaan problem solving dapat memacu siswa untuk berfikir, kreatif dalam mencari pemecahan masalah dari permasalahan yang diberikan, siswa akan lebih termotivasi dan tertantang.

Tidak terjadinya interaksi antara kedua variabel dengan media pembelajaran yang dpergunakan karena pada Multimedia Flash dan VCD Pembelajaran disebabkan karena masih kurang menekankan pada "hands on activity" dan lebih banyak kegiatan diskusi berdasarkan animasi atau video yang ditayangkan. Siswa yang kreatif selalu menyukai tantangan, permasalahan yang membutuhkan jawaban atau problem solving, sementara kedua media kurang dilengkapi dengan aktivitas "hands on" seperti misalnya praktikum setelah melihat tayangan media yang disertai pertanyaan-pertanyaan yang diharapkan keterampilan proses sains yang dimiliki oleh siswa menjadi terlatih dan dapat dikembangkan.

\section{Kesimpulan dan Rekomendasi}

Kesimpulan yang dapat dikemukakan dan hasil penelitian ini adalah: (1) tidak terdapat pengaruh penggunaan Multimedia Flash dan VCD dengan model pembelajaran POE terhadap prestasi belajar siswa, (2) terdapat pengaruh kemampuan verbal tinggi dan rendah terhadap prestasi belajar afektif dan psikomotor, (3) tidak terdapat pengaruh kreativitas tinggi dan rendah terhadap prestasi belajar afektif dan psikomotor, namun pada prestasi belajar ranah kognitif terdapat pengaruh, (4) tidak terdapat interaksi antara Multimedia Flash dan VCD Pembelajaran dengan kemampuan verbal terhadap prestasi belajar ranah afektif dan psikomotor, namun pada prestasi belajar kognitif terjadi interaksi, (5) tidak terdapat interaksi antara Multimedia Flash dan VCD terhadap prestasi belajar psikomotor, namun pada prestasi belajar ranah kognitif dan afektif terdapat interaksi, (6) tidak terdapat interaksi antara kemampuan verbal dengan kreativitas siswa, (7) tidak terdapat interaksi atau pengaruh yang signifikan antara Multimedia Flash dan VCD, kemampuan verbal dan kreativitas siswa terhadap prestasi belajar ranah kognitif, afektif dan psikomotor.

Berdasarkan hasil penelitian ini disarankan hal-hal sebagai berikut: (1) model $P O E$ dapat dijadikan strategi alternatif dalam pembelajaran di SMP dengan lebih menggunakan soal-soal problem solving, (2) perlu dilakukan penelitian pererapan penggunakan Multimedia Flash dan VCD untuk pokok bahasan IPA lainnya di tingkat SMP, dan (3) pembelajaran menggunakan media pembelajaran dengan model $\mathrm{POE}$ hendaknya lebih memperhatikan keterampilan proses sains dan kemampuan berfikir dari masing-masing siswa.

\section{Daftar Pustaka}

Falvo, D. (2008). Animations and simulations for teaching and learning molecular chemistry. International Journal of Technology in Teaching and Learning, 4: 68-77.

Kearney, Matthew, David F. Treagust, Shelley Yeo and Marjan G. Zadnik. (2001). Student and Teacher Perceptions of the Use of Multimedia Supported Predict-Observe-Explain Tasks to Probe Understanding. Research in Science Education. 31: 589-615.

Koroghlanian, Carol, Klein, James D. (2004). The Effect of Audio and Animation in Multimedia Instruction. Journal of Educational Multimedia and Hypermedia, 13(1) : 23-46. 
ISSN: 2252-7893, Vol 2, No 12013 (hal 25-32)

http://jurnal.fkip.uns.ac.id/index.php/sains

Liversidge, Tony, Matt Cochrane, Bernard Kerfoot, Judith Thomas. (2009). Teaching Science. London : SAGE Publication Inc.

Matthew, T. Mccrudden \& Alice J. Corkill. (2010). Verbal Ability And The Processing Of Scientific Text With Seductive Detail Sentences. Reading Psychology, 31:282-300.

Munandar, Utami. (1999). Pengembangan Kreativitas Anak Berbakat. Jakarta: Rineka Cipta.

Nurjanah, Ai. (2010). Penerapan model Pembelajaran Predict-observe-explain (POE) terhadap Peningkatan penguasaan Konsep Tekanan dan Keterampilan Berfikir Kreatif Siswa MTs. Jurnal Penelitian Pendidikan IPA. vol 4 (1) 86-90 oleh UPI.

Sumarni, Woro, Soeprodjo, Krida Puji Rahayu. (2009). Efektivitas Penerapan Metode Kasus Menggunakan Media Audio-Visual Terhadap Hasil Belajar Kimia Siswa SMA. Jurnal Inovasi Pendidikan Kimia. 3(1): 345-353.

Wikara, Bertha. (2010). Pembelajaran Biologi Melalui Media Komik Dan Animasi Ditinjau Dari Kemampuan Verbal dan Kreativitas Siswa. Tesis: Program Pendidikan Sains Program Pascasarjana Universitas Sebelas Maret Surakarta.

Winkel. (1999). Psikologi Pengajaran. Jakarta: Gramedia. 